\title{
PERSPECTIVES TO DESCRIBE SURFACE PROPERTIES OF RAW PHARMACEUTICAL MATERIALS. A FRACTAL APPROACH ON THE WETTING OF POWDERS
}

\author{
RĂZVAN MIHAI PRISADA ${ }^{1 *}$, CRISTINA-ELENA DINU-PÎRVU ${ }^{1 \#, ~ H O R A T ̦ I U ~ M O L D O V A N ~}{ }^{2 \#}$, \\ MIHAELA VIOLETA GHICA ${ }^{1 *}$, ROXANA-ELENA AVRĂMESCU ${ }^{1}$, LĂCRĂMIOARA POPA ${ }^{1}$ \\ 1 "Carol Davila” University of Medicine and Pharmacy, 6 Traian Vuia Street, 020956, Bucharest, România \\ ${ }^{2}$ University Politehnica of Bucharest, 313 Splaiul Independentei, 060042, Bucharest, Romania
}

*corresponding author: mihaelaghica@yahoo.com

\#Authors with equal contribution.

Manuscript received: November 2019

\begin{abstract}
Surface science is a currently expanding field which attracts attention through numerous possible correlations between different superficial phenomena. Modern approaches regarding superficial properties include extreme wetting interpretations through adapted regimes. Moreover, innovative applications arise from special surface properties like superhydrophilicity/ superhydrophobicity, through biomimicry, improving classic materials or generating new better artificial ones, of important interest in many domains. Liquid marbles, known as superhydrophobic-like structures also gained researcher's attention due to their special superficial properties. Experimental data in this direction are scarce, especially regarding active ingredients in the pharmaceutical domain and taking into account different morphologies and formulation versatility of liquid marbles. This paper focuses on anti-inflammatory powders and their superficial properties as raw pharmaceutical materials, but also as liquid marbles' components (external phases). Interpretations concern powders wettability degree expressed through contact angles and apparent contact angles of corresponding liquid marbles. These wetting parameters are correlated through a mathematical model, which also allows evaluation of fractal quantitative indexes: rugosity and fractal dimension. Applying a fractal wetting model to anti-inflammatory powders represents a step forward towards proposing contact angles and other wetting parameters as key indicators in pre-formulation processes. Dissolution and absorption of active ingredients are only two examples of processes in which a drug's pharmacokinetic profile is directly correlated to wetting parameters of its components. The importance of predicting a pharmaceutical products' behaviour is crucial in designing new products, making superficial properties investigations mandatory steps of the process.
\end{abstract}

\section{Rezumat}

Domeniul „Ştiința suprafețelor” este unul aflat în curs de expansiune şi atrage atenția prin numeroase posibile corelații între fenomenele superficiale. Abordări moderne ale proprietăților superficiale includ interpretări ale fenomenelor extreme de umectare, realizate prin intermediul regimurilor de udare adaptate. Mai mult, aplicații inovative derivă din proprietăți superficiale speciale precum superhidrofobia/superhidrofilia. Prin intermediul biomimetismului, materiale clasice sunt îmbunătățite. Totodată, sunt fabricate materiale noi cu caracteristici superioare, de interes în numeroase domenii. „Liquid marbles", exponenți ai comportamentului de tip superhidrofob, au atras atenția cercetătorilor prin proprietățile superficiale deosebite. Având în vedere versatilitatea formulării şi morfologiei „liquid marbles”, datele experimentale în direcția caracterizării lor sunt insuficiente. Aceasta se aplică mai ales în legătură cu domeniul farmaceutic, referitor la substanţele active. Prezenta lucrare se concentrează asupra pulberilor antiinflamatorii și proprietăților superficiale, atât ca materii prime farmaceutice, cât și ca faze externe ale „liquid marbles”, formulate cu pulberi omoloage. Sunt propuse interpretări privind gradul de umectare al pulberilor exprimat prin intermediul unghiului de contact, respectiv unghiul de contact aparent al "liquid marbles". Acești parametri sunt corelaţi, prin intermediul unor modele matematice, cu indici cantitativi specifici geometriei fractale: rugozitatea și dimensiunea fractală. Aplicarea unui model fractal al umectării adresat pulberilor antiinflamatorii reprezintă un pas înainte spre propunerea unghiului de contact şi a parametrilor umectării drept indicatori cheie ai umectării în studiile de preformulare farmaceutică adresate pulberilor. Importanţa anticipării comportamentului medicamentelor este crucială în proiectarea unor noi produse, astfel încât investigarea proprietăţilor superficiale devine o etapă obligatorie a procesului.

Keywords: surface properties, pharmaceutical anti-inflammatory powders, wetting models, "liquid marbles", fractal interpretation of wetting phenomena

\section{Introduction}

During the last decades, technological expansion projected itself upon diverse industrial areas, with appreciated and valuable acknowledgements. Among the scientific fields that benefited from industrial outgrow, microscopical analysis stood out, as many 
natural phenomena and properties were scientifically explained [9, 10, 16]. This progress was achieved due to the possibility to study surface properties at a macroscopic, microscopic and especially nanometric level [10, 29]. Thus, intrinsic properties of materials were correlated with surface properties, giving the latter a more precise interpretation. In particular, in order to define surface properties, a drop is considered in contact with a solid. Wetting phenomena are described through quantitative indexes: contact angle $\left(\mathrm{CA}\left(^{\circ}\right)\right)$ and other quantitative indexes: "sliding" contact angle, hysteresis, dynamic contact angle, surface tension, length $(\mathrm{mm})$, height $(\mathrm{mm})$, volume $(\mu \mathrm{L})$ and area $\left(\mathrm{mm}^{2}\right)$ of the drop, which is considered in this case, a spherical cap and not a perfect sphere [26, 27]. The contact angle $\left(\theta\right.$ or $\left.\mathrm{CA}\left({ }^{\circ}\right)\right)$ is determined using Young's equation:

$$
\cos \theta=\left(\gamma_{\mathrm{SG}}-\gamma_{\mathrm{SL}}\right) / \gamma_{\mathrm{LG}}
$$

Where $\gamma_{\mathrm{SG}}, \gamma_{\mathrm{SL}}, \gamma_{\mathrm{LG}}$ represent superficial tensions at the solid-gas, solid-liquid, liquid gas interfaces, and only applies to ideal, smooth surfaces $[3,10,11]$. It is important to emphasize that most of the surrounding surfaces are not perfectly smooth. Thus, Young's law does not apply. Other wetting models describe real surfaces, which exhibit rugosities. The most outstanding of these wetting regimes are Wenzel and CassieBaxter, which take into account the roughness (r) of the surface, making it possible to determine an apparent contact angle $\left(\mathrm{CA}^{*}\left(^{\circ}\right)\right.$ or $\left.\theta^{*}\right)$, through the following equation $[3,24,36,37]$ :

$$
\cos \theta^{*}=r \cdot\left(\gamma_{\mathrm{SG}}-\gamma_{\mathrm{SL}}\right) / \gamma_{\mathrm{LG}} \quad(\mathrm{Eq} 2)
$$

These regimes are characteristic to 'extreme' wetting situations, like superhydrophobicity and superhydrophilicity. Important exponents of a superhydrophobic behaviour are liquid marbles, structures known by their special architecture and properties [1, 2, 4, 7]. Exacerbated superficial properties are also exhibited by natural surfaces such as the lotus leave, the rose petal, butterfly wings, etc. have special surface topographies $[5,6,30,35]$. It can be considered that these surface designs comply to fractal morphologies. It is well known that a fractal is an irregular and complex structure, formed as a result of dividing a geometric figure into smaller fragments, which replicate following a pattern $[17,19,22,31]$.

The fractal concept gained life through the necessity of understanding complex natural architectures like the tree's crowns, inflorescences, snowflakes, waves, seashores, etc. [21, 25, 28]. Moreover, the fractal interpretation can be transposed further from natural elements to components of the human body: the brain and the neural network, the circulatory system, DNA structure, etc. [28]. Interpretation of fractal dimensions is different from the Euclidian one, which quantifies dimension using length and area. The fractal dimension (D) is used to characterize a fractal-structured object meaning the number of variables necessary to describe the object (e.g. a point-D $=0$, a line-D $=1$, a plane$\mathrm{D}=2$, a cube- $\mathrm{D}=3$, etc.). In other words, the fractal dimension is a complexity indicator of an object's auto-similarity [23, 25]. Fractal interpretations gained popularity in the cartographic field, offering the possibility to approximate dimensions, depending on the zoom level and determination scale [19, 22]. Nowadays, fractals are common in medical practices as supplementary screening methods in imagistic analysis. Images provided by magnetic resonance, computer topographies and ultrasounds, are segmented allowing signalling of homogeneity or lacunarity in tissues. They are considered additional markers of mammary cancer, as indicators of cancerous micro calcifications detected through mammography [15]. Also, interpreting electro-encephalograms and electrocardiograms through fractal geometry is considered of high importance in explaining modifications specific to cardiac diseases [33], neurodegenerative diseases, or investigating the disequilibrium in the trabecular bone system responsible for osteoporosis [20]. Fractals also enhanced the procedures of developing landscapes in video games and movie scenes, by offering the possibility to create an endless amount of content, which can be observed at different scales [8].

Fractal topography is considered the missing piece of the puzzle in different fields, particularly in "extreme" wettability surfaces engineering. As this kind of interpretation is still in the pioneering stage, the experimental part of this paper addresses a fractal approach on superficial properties of raw pharmaceutical materials, as a modern approach. The presented experiments focus on powders, as data regarding their superficial properties are still scarce. Recent research data include studies on polymeric mixtures and colloidal dispersions with chitosan intended for ocular administration and topical anti-inflammatory spongious matrices [12-14, 18, 32]. Relevant modern approaches on powders' wetting phenomena are possible, by including them in special structures called liquid marbles. This makes it possible not only to determine the wetting degree of the powder through the classic quantitative index (contact angle), but also to characterize liquid marbles (formulated with homologous powders) by apparent contact angles $\left(\left(\mathrm{CA}^{*}\left(^{\circ}\right)\right)\right.$. The experiments are conducted by following original and adapted protocols, reproducible for other similar pharmaceutical systems (powders) and will be presented next.

\section{Materials and Methods}

Pharmaceutical powders of substances with antiinflammatory action were selected as raw materials: salicylic acid (Chemical Company, Romania), niflumic acid (ICN Biomedicals, USA), ketoprofen, indomethacin, phenylbutazone and Lycopodium spores, as a model hydrophobic powder (Sigma Aldrich). Distilled water 
and glycerol (Sigma Aldrich) were used to conduct wetting parameters' determinations: contact angle $\mathrm{CA}\left({ }^{\circ}\right)$, length $(\mathrm{mm})$, height $(\mathrm{mm})$, volume $(\mu \mathrm{L})$ and area $\left(\mathrm{mm}^{2}\right)$ of the drop, which is considered in this case, a spherical cap and not a perfect sphere. The experimental set-up includes the CAM $101 \mathrm{KSV}$ Instruments goniometer, a Hamilton syringe with the appropriate needle (Biolin Scientific C209-22), microscope lamellae and a sieve (VEB Metallweberei Neustadt).

Effective surface properties determinations for the selected powders, are conducted following an original protocol developed in the Physical and Colloidal Chemistry Department from the Faculty of Pharmacy, as follows: (i) the powders are sieved onto the microscope lamellae previously treated with adhesive material, to ensure stability during experiments; (ii) water/glycerol drops are dispensed onto the powder bed, while images and data are recorded by the goniometer; (iii) wetting parameters evaluation takes place after selecting proper fitting regimes and the results are exported via tables. In the next experimental stage, the hydrophobic powders are included as external phases (shells) in liquid marbles formulations, using water and glycerol as internal phases. The formations are obtained using the same set-up, with the difference that the drops are dispensed and immediately rolled onto a watch glass, covered in a hydrophobic powder bed. Thus, anti-inflammatorycovered liquid marbles are obtained.

The last phase of the research includes liquid marbles' characterization from a superficial properties point of view. An apparent contact angle $\left(\left(\mathrm{CA}^{*}{ }^{\circ}\right)\right)$ is determined for the liquid marbles placed on a glass microscope lamella, using the goniometer. The powder shell-glass interface is considered, in order to fit the liquid marble as a geometric form and conduct suitable determinations. This method was developed as an adaptation of the one used for powders and successfully applies for other liquid marble-like structures. All experimental data were processed as graphical representations using OriginPro 8.5.

\section{The fractal interpretation of wetting}

In order to develop a modern approach on powder wettability, a fractal interpretation was proposed for a drop placed in contact with a fractal surface, as presented in Figure 1.

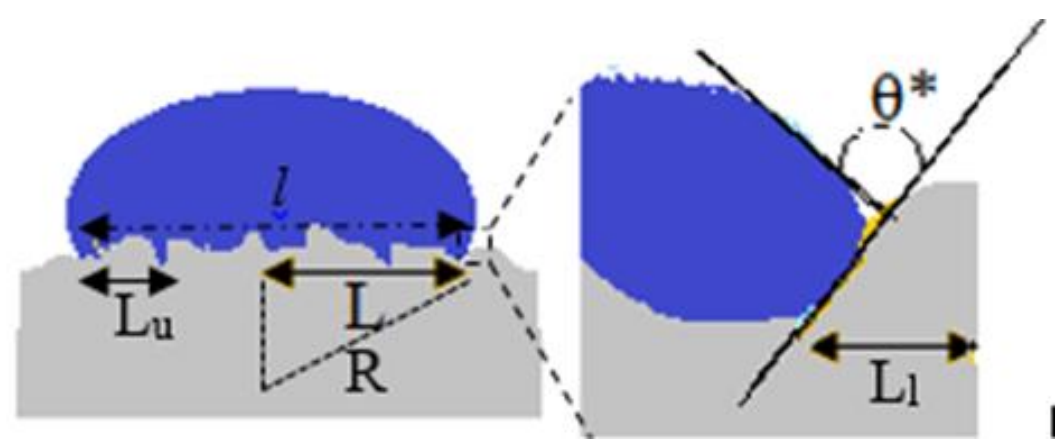

Figure 1.

Scale association between Wenzel and fractal model (R-sphere radius, $l$ - drop-surface interface length, $\mathrm{L}_{\mathrm{u}}, \mathrm{L}_{\mathrm{l}}^{-}$ upper and lower bound of the fractal region, $\mathrm{L}=l / 2$ - contact area length)

It is important to mention that drops in contact with surfaces are considered caps (with radius $r_{c}$ ), whilst the sphere radius is $\mathrm{R}$ and sphere cap height is $\mathrm{H}$, where:

$$
\mathrm{R}=\mathrm{r}_{\mathrm{c}}^{2}+\mathrm{H}^{2} / 2 \mathrm{H} \quad(\mathrm{Eq} 3)
$$

Contact angles $(\theta)$ and apparent contact angles $\left(\theta^{*}\right)$ are correlated through Wenzel's equation, with surface rugosity (r) and fractal dimension (D) through a calculation model. The rugosity coefficient is determined as:

$$
r=\cos \theta * / \cos \theta \quad(\mathrm{Eq} 4)
$$

In general, for real rough surfaces, $r \geq 1$. In order to relate the apparent contact angle from Wenzel's model to fractal surfaces, the following equation is proposed:

$$
\cos \theta^{*}=\left(\mathrm{L}_{\mathrm{u}} / \mathrm{L}_{\mathrm{l}}\right)^{(\mathrm{D}-2)} \cdot \cos \theta \quad(\mathrm{Eq} 5)
$$

Where $\mathrm{L}_{\mathrm{u}}, \mathrm{L}_{1}$ represent the upper and lower bounds of the fractal region. For our case, the characteristic length of the contact area $\mathrm{L}$ is between the upper and lower bounds $\mathrm{L}_{\mathrm{l}}<\mathrm{L}<\mathrm{L}_{\mathrm{u}}$ and the apparent contact angle may be defined as equation 6 [34]:

$$
\cos \theta^{*}=\left(\mathrm{L}_{\mathrm{L}} \mathrm{L}^{(\mathrm{D}-2)} \cdot \cos \theta \quad(\mathrm{Eq} 6)\right.
$$

The characteristic length of the contact liquid-solid area $\mathrm{L}$ can be estimated as shown in equation 7:

$$
\mathrm{L}=\mathrm{R} \cdot \sin \theta^{*} \quad(\mathrm{Eq} 7)
$$

Thus, the apparent contact angle and radius $\mathrm{r}$ become equation 8 :

$$
\mathrm{r}=\left(\mathrm{R} \cdot \sin \theta^{*} / \mathrm{L}_{\mathrm{l}}\right)^{(\mathrm{D}-2)}
$$

Because water drops are millilitre-sized and fractal rugosities are nanometrical, a size correction of $10^{-3}$ is required and $\mathrm{L}_{l}$ is assumed as $1 \mathrm{~nm}$.

This mathematical model allows a fractal interpretation upon powders' wetting, correlating the contact angle with the apparent contact angle of liquid marbles formulated with homologous powders. 


\section{Results and Discussion}

All the investigated powders exhibited high contact angle values, both for water and glycerol as model fluids $\left(\mathrm{CA}_{\mathrm{w}}\left({ }^{\circ}\right), \mathrm{CA}_{\mathrm{g}}\left({ }^{\circ}\right)\right)$, indicating a hydrophobic character. Results are presented in Tables I and II where
AS-salicylic acid, AN-niflumic acid, K-ketoprofen, F-phenylbutazone, I-indomethacin, LY-Lycopodium, l-length $(\mathrm{mm}), \mathrm{H}$-height $(\mathrm{mm}), \mathrm{V}$-volume $(\mu \mathrm{L})$ and A-area $\left(\mathrm{mm}^{2}\right)$. Figure 2 presents images recorded during the superficial properties' evaluations.

Table I

Wetting parameters evaluation results for water as model fluid

\begin{tabular}{|c|c|c|c|c|c|}
\hline Powder & $\mathbf{C A w}\left({ }^{\circ}\right)$ & $\mathbf{l}(\mathbf{m m})$ & $\mathbf{H}(\mathbf{m m})$ & $\mathbf{V}(\boldsymbol{\mu L})$ & $\mathbf{A}\left(\mathbf{m m}^{\mathbf{2}}\right)$ \\
\hline $\mathbf{A S}$ & $106.66 \pm 2.60$ & $2.72 \pm 0.18$ & $1.78 \pm 0.08$ & $8.19 \pm 1.14$ & $15.82 \pm 1.44$ \\
\hline $\mathbf{A N}$ & $125.75 \pm 1.78$ & $2.40 \pm 0.10$ & $1.86 \pm 0.05$ & $7.57 \pm 0.66$ & $15.37 \pm 0.87$ \\
\hline $\mathbf{K}$ & $127.35 \pm 1.56$ & $2.10 \pm 0.05$ & $2.08 \pm 0.01$ & $8.31 \pm 0.12$ & $24.78 \pm 7.09$ \\
\hline $\mathbf{F}$ & $107.31 \pm 2.75$ & $2.60 \pm 0.06$ & $1.77 \pm 0.07$ & $7.59 \pm 0.58$ & $15.14 \pm 0.82$ \\
\hline $\mathbf{I}$ & $105.05 \pm 3.05$ & $2.64 \pm 0.11$ & $1.72 \pm 0.08$ & $7.45 \pm 0.80$ & $14.86 \pm 1.07$ \\
\hline $\mathbf{L Y}$ & $94.00 \pm 1.29$ & $2.60 \pm 0.39$ & $1.47 \pm 0.13$ & $5.68 \pm 1.87$ & $12.16 \pm 2.65$ \\
\hline
\end{tabular}

Table II

Wetting parameters evaluation results for glycerol as model fluid

\begin{tabular}{|c|c|c|c|c|c|}
\hline Powder & $\mathbf{C A g}\left(^{\circ}\right)$ & $\mathbf{l}(\mathbf{m m})$ & $\mathbf{H}(\mathbf{m m})$ & $\mathbf{V}(\boldsymbol{\mu L})$ & $\mathbf{A}\left(\mathbf{m m}^{\mathbf{2}}\right)$ \\
\hline $\mathbf{A S}$ & $106.13 \pm 2.01$ & $3.03 \pm 0.21$ & $2.01 \pm 0.29$ & $11.02 \pm 0.89$ & $19.69 \pm 0.40$ \\
\hline $\mathbf{A N}$ & $11.50 \pm 1.66$ & $2.76 \pm 0.16$ & $1.69 \pm 0.19$ & $9.97 \pm 1.01$ & $19.19 \pm 1.92$ \\
\hline $\mathbf{K}$ & $129.69 \pm 0.88$ & $2.91 \pm 0.23$ & $2.24 \pm 0.14$ & $12.86 \pm 0.43$ & $20.93 \pm 0.87$ \\
\hline $\mathbf{F}$ & $113.55 \pm 3.94$ & $2.55 \pm 0.12$ & $1.95 \pm 0.06$ & $8.89 \pm 0.23$ & $17.09 \pm 0.39$ \\
\hline $\mathbf{I}$ & $115.77 \pm 3.55$ & $2.68 \pm 0.30$ & $2.14 \pm 0.27$ & $11.55 \pm 4.32$ & $20.26 \pm 4.99$ \\
\hline $\mathbf{L Y}$ & $109.38 \pm 1.67$ & $2.89 \pm 0.23$ & $2.04 \pm 0.14$ & $11.13 \pm 2.75$ & $19.74 \pm 3.08$ \\
\hline
\end{tabular}

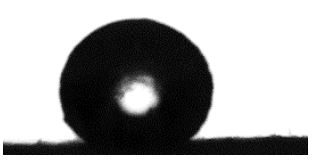

$\mathrm{CA}_{\mathrm{w}}\left({ }^{\circ}\right)=109.42^{\circ}$

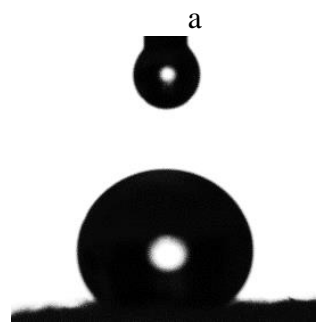

$\mathrm{CAg}^{\circ}\left({ }^{\circ}\right)=116.12^{\circ}$

d

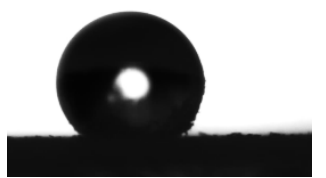

$\mathrm{CA}_{\mathrm{w}}\left({ }^{\circ}\right)=107.09^{\circ}$

b

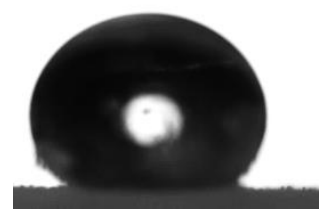

$\mathrm{CA}_{\mathrm{g}}\left({ }^{\circ}\right)=115.91^{\circ}$

e

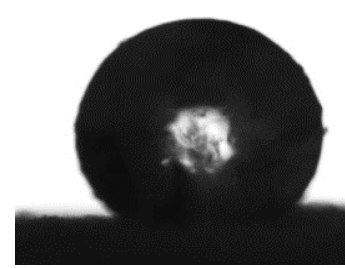

$\mathrm{CA}_{\mathrm{w}}\left({ }^{\circ}\right)=123.73^{\circ}$

c

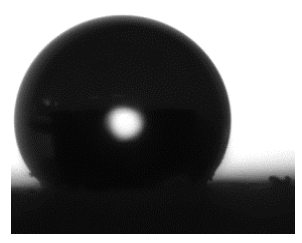

$\mathrm{CAg}_{\mathrm{g}}\left({ }^{\circ}\right)=128.99^{\circ}$

$\mathrm{f}$

Figure 2.

Examples of images recorded during contact angle evaluations: a, d - phenylbutazone; $\mathrm{b}$, e - indomethacin;

c, f - ketoprofen

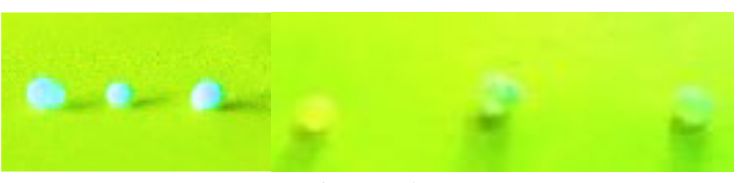

Figure 3.

Anti-inflammatory-coated liquid marbles: salicylic acid, niflumic acid, ketoprofen, Lycopodium, indomethacin, phenylbutazone (from left to right)

The powders' hydrophobicity indicated the possibility to include them in liquid marbles formulations. Liquid marbles obtained by rolling water and glycerol droplets in hydrophobic powder beds are presented in Figure 3. After manufacturing liquid marbles, the investigations concerning their superficial behaviour indicate, through apparent contact angle values $\left(\mathrm{CA}_{\mathrm{w}} *\left(^{\circ}\right), \mathrm{CA}_{\mathrm{g}} *\left(^{\circ}\right)\right)$, a superhydrophobic-like character, as presented in Tables III and IV. Representative images recorded during superficial properties evaluations are presented in Figure 4. 
Table III

Wetting parameters evaluation results for water as model fluid

\begin{tabular}{|c|c|c|c|c|c|}
\hline Powder & $\mathbf{C A w} *(\mathbf{})$ & $\mathbf{l}(\mathbf{m m})$ & $\mathbf{H}(\mathbf{m m})$ & $\mathbf{V}(\boldsymbol{\mu L} \mathbf{L})$ & $\mathbf{A}\left(\mathbf{m m}^{\mathbf{2}}\right)$ \\
\hline $\mathbf{A S}$ & $121.50 \pm 1.54$ & $2.55 \pm 0.25$ & $2.15 \pm 0.39$ & $13.28 \pm 2.27$ & $17.39 \pm 3.10$ \\
\hline $\mathbf{A N}$ & $127.03 \pm 1.95$ & $1.93 \pm 0.15$ & $2.00 \pm 0.18$ & $9.47 \pm 1.31$ & $16.12 \pm 3.34$ \\
\hline $\mathbf{K}$ & $136.51 \pm 0.72$ & $1.96 \pm 0.57$ & $1.84 \pm 0.16$ & $8.36 \pm 1.59$ & $17.21 \pm 1.25$ \\
\hline $\mathbf{F}$ & $123.31 \pm 1.32$ & $2.26 \pm 0.2$ & $1.93 \pm 0.13$ & $7.68 \pm 1.01$ & $15.78 \pm 1.49$ \\
\hline $\mathbf{I}$ & $122.62 \pm 1.71$ & $2.02 \pm 0.16$ & $1.93 \pm 0.05$ & $6.88 \pm 0.59$ & $14.92 \pm 0.77$ \\
\hline $\mathbf{L Y}$ & $110.78 \pm 3.17$ & $2.34 \pm 0.41$ & $1.63 \pm 0.11$ & $5.19 \pm 0.75$ & $11.97 \pm 1.04$ \\
\hline
\end{tabular}

Table IV

Wetting parameters evaluation results for glycerol as model fluid

\begin{tabular}{|c|c|c|c|c|c|}
\hline Powder & $\mathbf{C A g} *\left(^{\circ}\right)$ & $\mathbf{l}(\mathbf{m m})$ & $\mathbf{H}(\mathbf{m m})$ & $\mathbf{V}(\boldsymbol{\mu L})$ & Aria $\left(\mathbf{m m}^{\mathbf{2}}\right)$ \\
\hline $\mathbf{A S}$ & $121.46 \pm 1.73$ & $2.67 \pm 0.21$ & $2.01 \pm 0.29$ & $14.22 \pm 1.52$ & $21.93 \pm 1.09$ \\
\hline AN & $120.77 \pm 2.02$ & $2.66 \pm 0.22$ & $1.69 \pm 0.19$ & $22.60 \pm 1.60$ & $25.37 \pm 1.70$ \\
\hline K & $129.26 \pm 0.90$ & $2.86 \pm 0.85$ & $2.24 \pm 0.14$ & $10.11 \pm 1.54$ & $19.26 \pm 1.67$ \\
\hline F & $122.74 \pm 3.84$ & $2.61 \pm 0.21$ & $1.95 \pm 0.06$ & $13.61 \pm 1.27$ & $23.35 \pm 1.22$ \\
\hline $\mathbf{I}$ & $120.48 \pm 5.15$ & $2.37 \pm 0.15$ & $2.14 \pm 0.27$ & $9.94 \pm 1.16$ & $18.90 \pm 1.75$ \\
\hline LY & $109.6 \pm 1.23$ & $3.54 \pm 0.29$ & $2.04 \pm 0.15$ & $17.87 \pm 1.61$ & $27.47 \pm 1.21$ \\
\hline
\end{tabular}

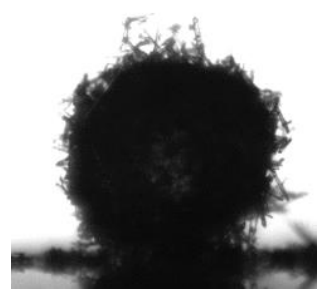

$\mathrm{CA}^{*}{ }_{\mathrm{w}}\left({ }^{\circ}\right)=123.46^{\circ}$

a

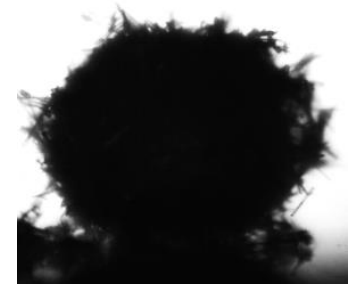

$\left.\mathrm{CA}^{*}{ }_{\mathrm{g}}{ }^{\circ}\right)=121.49^{\circ}$

d

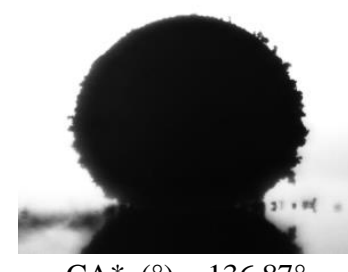

$\mathrm{CA}^{*}{ }_{\mathrm{w}}\left({ }^{\circ}\right)=136.87^{\circ}$

b

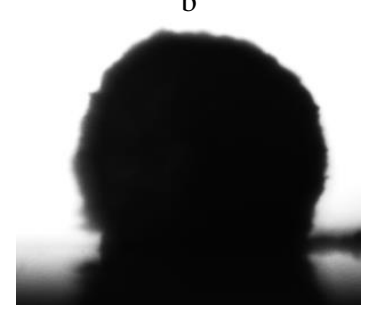

$\mathrm{CA}^{*}{ }_{\mathrm{g}}\left({ }^{\circ}\right)=129.81^{\circ}$

e

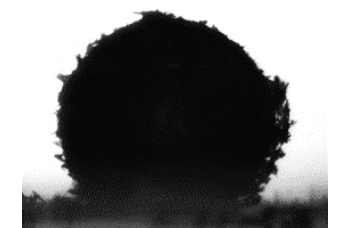

$\mathrm{CA}^{*}{ }_{\mathrm{w}}\left({ }^{\circ}\right)=124.21^{\circ}$

c

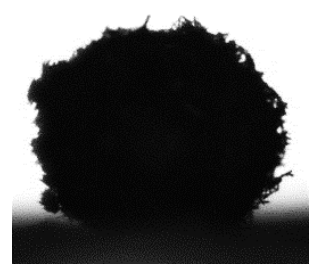

$\left.\mathrm{CA}^{*}{ }_{\mathrm{g}}{ }^{\circ}\right)=121.05^{\circ}$

f

Figure 4.

Examples of images recorded during contact angle evaluations: a - salicylic acid; b - ketoprofen; c -phenylbutazone

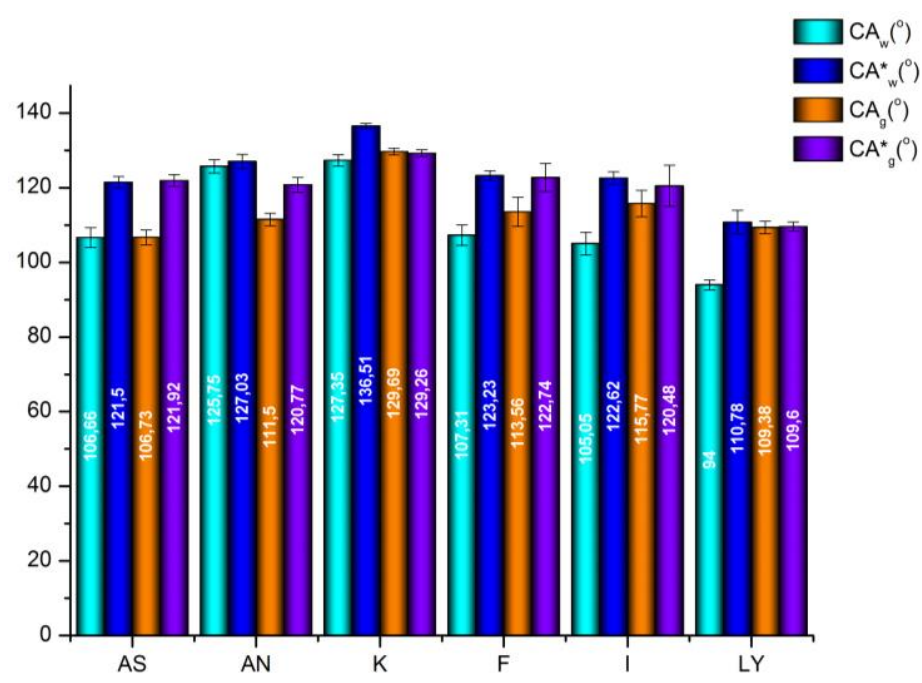

Figure 5.

Comparative representation for contact angles $\left(\mathrm{CA}_{\mathrm{w}}\left({ }^{\circ}\right), \mathrm{CA}_{\mathrm{g}}\left({ }^{\circ}\right)\right)$ and apparent contact angles $\left(\mathrm{CA}_{\mathrm{w}}\left(^{*}\right), \mathrm{CA}_{\mathrm{g}}{ }^{*}\left({ }^{\circ}\right)\right)$ 
A comparison between contact angle values and apparent contact angle values is graphically represented in Figure 5, emphasizing the higher values of apparent contact angles vs. contact angles, for homologous powders.

After applying the early presented mathematical model, fractal quantitative indicators, respectively rugosity coefficients for water and glycerol as model fluids $\left(r_{w}\right.$, $\left.r_{g}\right)$ and fractal dimensions $\left(D_{w}, D_{g}\right)$ are calculated. Corresponding results are presented in Table $\mathrm{V}$.

Table V

Fractal quantitative indexes evaluation results

\begin{tabular}{|c|c|c|c|c|}
\hline Powder & rw & rg & Dw & Dg \\
\hline AS & $1.850 \pm 0.230$ & $1.944 \pm 0.445$ & $2.086 \pm 0.017$ & $2.089 \pm 0.029$ \\
\hline AN & $1.032 \pm 0.059$ & $1.406 \pm 0.180$ & $2.004 \pm 0.008$ & $2.047 \pm 0.018$ \\
\hline K & $1.197 \pm 0.052$ & $0.990 \pm 0.020$ & $2.026 \pm 0.006$ & $1.998 \pm 0.002$ \\
\hline F & $1.895 \pm 0.423$ & $1.370 \pm 0.173$ & $2.088 \pm 0.028$ & $2.043 \pm 0.019$ \\
\hline I & $2.178 \pm 0.650$ & $1.170 \pm 0.161$ & $2.112 \pm 0.040$ & $2.021 \pm 0.019$ \\
\hline LY & $5.672 \pm 2.606$ & $1.020 \pm 0.143$ & $2.232 \pm 0.056$ & $2.001 \pm 0.019$ \\
\hline
\end{tabular}
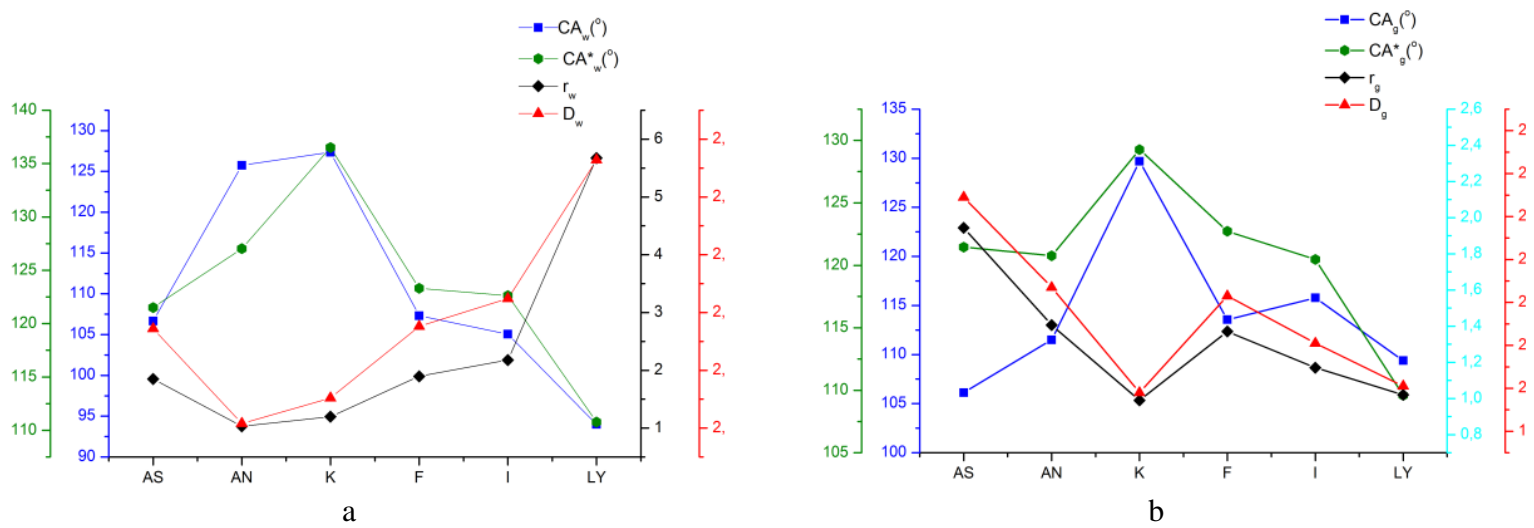

Figure 6.

Graphical interpretations of the inverse proportional relationship between superficial properties and fractal quantitative indicators, determined using water - $a$ and glycerol - $b$, as model fluids

A correlation between contact angles, respectively apparent contact angles and rugosity coefficient, fractal dimension is revealed. The graphical representation (Figure 6) reveals an inverse proportional relationship between the above-mentioned dimensions: high contact angles correspond to low values of rugosity and fractal dimensions.

The model proposed to correlate superficial properties with fractal dimensions reveals that a low rugosity coefficient determines a high hydrophobicity, justifying Wenzel's equation to calculate the apparent contact angle. The mathematical model is validated through very close values of the fractal dimensions $D_{w}, D_{g}$ (very small differences, between 0.003 and 0.231 ), demonstrating at the same time independency of the determinations from the model fluid.

\section{Conclusions}

The results of the scientific investigations regarding superficial properties of powders as raw pharmaceutical materials indicated, for the investigated powders, a hydrophobic character and the possibility to formulate liquid marbles. The high apparent contact angle of the marbles $\left(\mathrm{CA}^{*}\left(^{\circ}\right)>109^{\circ}\right)$ probe their superhydrophobic character. The protocols developed in order to evaluate the wetting properties of the powders and superficial characteristics of liquid marbles are original and adapted to the analysed materials. They proved accuracy and have the advantage of reproducibility for other similar pharmaceutical systems.

The correlation established between the contact angle as key wetting indicator, respectively between the apparent contact angle of liquid marbles and fractal geometry elements, rugosity and fractal dimension, represents a novel element in pre-formulation studies addressing pharmaceutical powders. The present study opens a gateway towards evaluating the contact angle, not only as wetting descriptor of powders involved in wet granulation, compression or solid dispersion formulation, but also in anticipating dissolution mechanisms of active ingredients from drugs. Interest is being addressed towards understanding dissolution speed in relationship with contact angle and wetting speed, in presence/absence of surfactants. Thus, the contact angle along with other parameters become more than wetting indicators. Their potential expands towards dissolution and absorption behaviour descriptors, with applicability in pharmaceutical form development processes following QbD (“Quality by Design”) principles. 


\section{Acknowledgement}

This paper was financially supported by „Carol Davila” University of Medicine and Pharmacy through Contract no. 23PFE/17.10.2018 funded by the Ministry of Research and Innovation within PNCDI III, Program 1 Development of the National RD system, Subprogram 1.2 - Institutional Performance - RDI excellence funding projects.

\section{Conflict of interest}

The authors declare no conflict of interest.

\section{References}

1. Aussillous P, Quéré D, Liquid marbles. Nature, 2001; 411(6840): 924-927.

2. Avrămescu RE, Ghica MV, Dinu-Pîrvu C, Popa L, Small scale manufacturing of anti-inflammatory powdercovered liquid marbles. An experimental approach on designing Pickering-like emulsions for topical application. Studia Universitatis "Vasile Goldiș", Seria Științele Vieții, 2018; 28(3): 144-151.

3. Avrămescu RE, Ghica MV, Dinu-Pirvu C, Prisada R, Popa L, Superhydrophobic natural and artificial surfaces-A structural approach. Materials (Basel), 2018; 11(5): 1-24.

4. Avrămescu RE, Ghica MV, Dinu-Pîrvu C, Udeanu D, Popa L, Liquid marbles: From industrial to medical applications. Molecules, 2018; 23(5): 1-30.

5. Bhushan B, Nosonovsky M, The rose petal effect and the modes of superhydrophobicity. Philosophical Transactions of the Royal Society A: Mathematical, Physical and Engineering Sciences, 2010; 368(1929): 4713-4728.

6. Bixler GD, Bhushan B, Bioinspired rice leaf and butterfly wing surface structures combining shark skin and lotus effects. Soft Matter., 2012; 8(44): 1127111284.

7. Bormashenko E, Liquid marbles: Properties and applications. Current Opinion in Colloid \& Interface Science, 2011; 16(4): 266-271.

8. Cristea A, Liarokapis F, Fractal Nature - Generating Realistic Terrains for Games. $20157^{\text {th }}$ International Conference on Games and Virtual Worlds for Serious Applications (VS-Games), 2015: 1-8.

9. Darmanin T, Guittard F, Superhydrophobic and superoleophobic properties in nature. Materials Today, 2015; 18(5): 273-285.

10. Dinu-Pîrvu CE, Avrămescu RE, Ghica MV, Popa L, Natural and artificial superwettable surface-superficial phenomena: an extreme wettability scenario. In Wettability and interfacial phenomena - Implications for material processing. IntechOpen, 2019: 121-143.

11. Extrand CW, Origins of wetting. Langmuir, 2016; 32(31): 7697-7706.

12. Ghica MV, Albu Kaya MG, Dinu-Pîrvu CE, Lupuleasa D, Udeanu, DI, Development, optimization and in vitro/in vivo characterization of collagen-dextran spongious wound dressings loaded with flufenamic acid. Molecules, 2017; 22 (9): 1-22.

13. Ghica MV, Albu MG, Kaya DA, Popa L, Öztürk Ș, Rusu LC, Dinu-Pîrvu C, Chelaru C, Albu L, Meghea
A, Nitipir C, The effect of Lavandula essential oils on release of niflumic acid from collagen hydrolysates. Korean J Chem Engin., 2016; 33(4): 1325-1330.

14. Ghica MV, Albu MG, Popa L, Moisescu S, Response surface methodology and Taguchi approach to assess the combined effect of formulation factors on minocycline delivery from collagen sponges. Pharmazie, 2013; 68 (5): 340-8.

15. Grizzi F, Fractal geometry as a tool for investigating benign and malignant breast mammography lesions. Fractal Geometry and Nonlinear Analysis in Medicine and Biology, 2015; 1(1): 16-18.

16. Guo Z, Liu W, Su BL, Superhydrophobic surfaces: From natural to biomimetic to functional. J Colloid Interface Sci., 2011; 353(2): 335-355.

17. Hazlett RD, Fractal applications: wettability and contact angle. J Colloid Interface Sci., 1990, 137(2): 527-533.

18. Irimia T, Mușat GC, Prisada RM, Ghica MV, DinuPîrvu CE, Anuţa V, Velescu BȘ, Popa L, Contributions on formulation and preliminary evaluation of ocular colloidal systems of chitosan and poloxamer 407 with bupivacaine hydrochloride. Farmacia, 2019; 67(4): 702-708.

19. Lin Y, Zhou R, Xu J, Superhydrophobic surfaces based on fractal and hierarchical microstructures using twophoton polymerization: Toward flexible superhydrophobic films. Adv Materials Interf., 2018; 5(21): 1-8.

20. Lopes R, Betrouni N, Fractal and multifractal analysis: A review. Medical Image Analysis, 2009; 13(4): 634-649.

21. Mandelbrot B, How long is the coast of Britain? Statistical self-similarity and fractional dimension. Science, 1967; 156(3775): 636-638.

22. Mandelbrot BB, The Fractal Geometry of Nature, W. H. Freeman and Co., United States, 1983; 51: 286-286.

23. Mannelqvist A, Grothhttps R, Comparison of fractal analyses methods and fractal dimension for pre-treated stainless steel surfaces and the correlation to adhesive joint strength. Applied Physics A, 2001; 73(347): 347355.

24. Nosonovsky M, Bhushan B, Hierarchical roughness makes superhydrophobic states stable. Microelectronic Engineering, 2007; 84: 382-386.

25. Nurujjaman M, A review of fractals properties: Mathematical approach. J Appl Mathemat., 2017; 5(3): 98-105.

26. Popa L, Ghica MV, Albu MG, Ortan A, Dinu-Pîrvu $\mathrm{CE}$, Hysteresis of contact angle. Dynamic wettability studies of collagen and doxycycline porous matrices crosslinked with tannic acid. Digest J Nanomater Biostruct., 2013; 8(3): 937-943.

27. Preoteasa CT, Nabil SA, Popa L, Ghica MV, Ionescu E, T,âncu AMC, Preoteasa E, Studies regarding the wettability of acrylic and silicone dental materials. Farmacia, 2011; 59(6): 871-878.

28. Spehar B, Clifford CWG, Newell BR, Taylor RP, Universal aesthetic of fractals. Computers \& Graphics, 2003; 27(5): 813-820.

29. Su Y, Ji B, Zhang K, Gao H, Huang Y, Hwang K, Nano to micro structural hierarchy is crucial for stable superhydrophobic and water-repellent surfaces. Langmuir, 2010; 26(7): 4984-4989. 
30. Tian Y, Su B, Jiang L, Interfacial material system exhibiting superwettability. Advanced Materials, 2014; 26(40): 6872-6897.

31. Tsujii K, Fractal materials and their functional properties. Polymer Journal, 2008, 40(9): 785-799.

32. Udeanu DI, Albu Kaya MG, Ghica MV, Marin MM, Marin S,, Kaya D A, Popa L, Dinu-Pîrvu C, Antiinflammatory drug-loaded biopolymeric spongious matrices with therapeutic perspectives in burns treatment. Farmacia, 2018; 66(5): 783-790.

33. Zappasodi F, Olejarczyk E, Marzetti L, Assenza G, Pizzella V, Tecchio F, Fractal dimension of EEG activity senses neuronal impairment in acute stroke. Plos One, 2014; 9(6): 1-8.
34. Zeng Q, Size matching effect on Wenzel wetting on fractal surfaces. Results in Physics, 2018; 10: 588-593.

35. Zhang M, Feng S, Wang L, Zheng Y, Lotus effect in wetting and self-cleaning. Biotribology, 2016; 5: 31-43.

36. Zhang P, Wang S, Wang S, Jiang L, Superwetting surfaces under different media: Effects of surface topography on wettability. SmallNanoMicro, 2015; 11(16): 1939-1946.

37. Zheng Q, Lü C, Size effects of surface roughness to superhydrophobicity. Procedia IUTAM, 2014; 10: 462-475. 